\title{
Brexpiprazole for the Treatment of Schizophrenia in Adults: An Overview of Its Clinical Efficacy and Safety and a Psychiatrist's Perspective
}

This article was published in the following Dove Press journal:

Drug Design, Development and Therapy

\section{Yoshinori Watanabe' Sakiko Yamada $\mathbb{D D}^{2}$ \\ Tempei Otsubo ${ }^{3}$ \\ Toshiaki Kikuchi ${ }^{4}$}

'Himorogi Psychiatric Institute, Tokyo, Japan; ${ }^{2}$ Medical Affairs, Otsuka Pharmaceutical Co. Ltd, Tokyo, Japan; ${ }^{3}$ Department of Psychiatry, Tokyo Women's Medical University Medical Center East, Tokyo, Japan; ${ }^{4}$ Department of Neuropsychiatry, Keio University School of Medicine, Tokyo, Japan
Correspondence: Yoshinori Watanabe Himorogi Psychiatric Institute, 2-3I-2 Ichigayatamachi, Shinjuku-ku, Tokyo 162 0843, Japan

Tel +8I-3-5946-8586

Email watanabe@himorogi.org

\begin{abstract}
While the prognosis of patients with schizophrenia has dramatically improved after the advent of chlorpromazine, the antipsychotics currently available are so numerous that it has become a challenge for psychiatrists to choose from among these drugs for each patient presenting for care. In addition, while numerous studies show that an effective antipsychotic should be continued indefinitely to prevent relapses or worsening, many patients appear to have difficulty remaining on any drug thus initiated. Brexpiprazole, a dopamine $\mathrm{D}_{2}$ receptor partial agonist, appears to provide a unique profile that has much to offer in this light. Specifically, this novel drug is potentially better suited for long-term use, with decreased risk of extrapyramidal side effects, hyperprolactinemia, weight gain, psychosis, insomnia, akathisia, nausea/vomiting or restlessness, thus potentially facilitating patients' reintegration into society. Indeed, brexpiprazole has been shown in randomized, double-blind, placebo-controlled trials to have proven efficacy not only in improving the symptoms of schizophrenia but in preventing relapses. It is also suggested in both short- and long-term studies that brexpiprazole offers a favorable safety and tolerability profile. This review also includes a proposed treatment algorithm incorporating brexpiprazole, based on the clinical trial results available, as well as on the authors' clinical experience, where brexpiprazole may be best used as a drug of first choice for the treatment of schizophrenia. Thus, overall, brexpiprazole appears to play a more significant role in the treatment of schizophrenia than other antipsychotics.
\end{abstract}

Keywords: brexpiprazole, dopamine $\mathrm{D}_{2}$ receptor partial agonist, efficacy, safety, schizophrenia, treatment algorithm

\section{Introduction (Including the Pharmacology of Brexpiprazole)}

Characterized by its hallmark symptoms (ie, hallucination and delusion), schizophrenia represents one of the most debilitating mental disorders, with its prevalence being as high as $0.1 \%$ to $0.4 \%{ }^{1-3}$ Schizophrenia has been regarded as a progressive disease with poor prognosis, which occurs initially during adolescence and young adulthood and follows a chronic course as it manifests highly variable mental symptoms and recurs repeatedly.

While the prognosis of patients with schizophrenia has dramatically improved following the clinical development in 1952 of chlorpromazine (CP), ${ }^{4,5}$ the antipsychotic drugs that have been developed since are so numerous that it has become quite a challenge for psychiatrists to choose from among these drugs for each 
patient presenting to the clinic. For example, in 2019, the FDA approved in the US a new antipsychotic and dopamine $D_{2}$ receptor partial agonist, lumateperone, for the treatment of schizophrenia. As a consequence, psychiatrists have found themselves compelled to draw on their own clinical experience to do so. In an attempt to address this challenge, Huhn et al conducted a network metaanalysis of randomized, double-blind, placebo-controlled trials of 32 oral antipsychotics to compare and rank these drugs in terms of overall safety and efficacy, ${ }^{6}$ which demonstrated that, of these, brexpiprazole (Rexulti ${ }^{\circledR}$; Otsuka Pharmaceutical Co, Ltd, Tokyo, Japan), the focus of the present review, ranks low. However, brexpiprazole appears to be a viable option for an acute exacerbation of schizophrenia in the clinical setting. ${ }^{7}$ While numerous studies show that any effective antipsychotic initiated in a patient with schizophrenia needs to be continued almost for life or indefinitely to prevent relapses or worsening, ${ }^{8}$ quite a few patients appear to have difficulty remaining on any drug thus initiated, suggesting that it is its overall efficacy/tolerability profile that really counts. Typically, following 6 weeks of acute-phase treatment, such as that implemented in clinical trials, it is the task of psychiatrists to treat patients with schizophrenia over the long term with a wide array of antipsychotics by repeated trials, ie, through upward/downward dose titrations, switching of drugs, and monitoring of drug responsiveness and adverse events, until finally, they have found one that is likely to prevent relapses and thus endure for life; it is also deemed psychiatrists' task in this process to provide support to facilitate their community (re)integration, ie, to allow them to live, participate and socialize in their community.

A dopamine $\mathrm{D}_{2}$ receptor partial agonist, brexpiprazole appears to provide a unique profile that has much to offer, contrary to the above-mentioned meta-analysis. ${ }^{6}$ Brexpiprazole, which was developed in Japan, may be better suited for long-term use in patients with schizophrenia over other atypical antipsychotics, with low risk of hyperprolactinemia, ${ }^{9}$ with low risk of super-sensitivity psychosis due to dopamine $\mathrm{D}_{2}$ receptor sensitization in animal models ${ }^{10}$ and with decreased risk of insomnia, akathisia, nausea/vomiting or restlessness in a majority of cases, ${ }^{11}$ thus potentially facilitating patients' community integration.

In what follows, therefore, based on a review of the literature on brexpiprazole as well as our increasing clinical experience with the drug, brexpiprazole will be explored for its role in schizophrenia, in terms of its efficacy/safety implications and clinical applications.

\section{Pharmacological Characteristics and Development of Brexpiprazole}

In 1972, Arvid Carlsson et al discovered the existence of a presynaptic receptor (auto-receptor) involved in the down-regulation of dopamine synthesis and release, as well as dopaminergic neuron firing. ${ }^{12}$ This key finding, among others, contributed to the conceptual underpinnings of early psychopharmacological research. Over a decade later, OPC-14597 (aripiprazole), both an agonist at presynaptic dopamine $\mathrm{D}_{2}$ receptor and an antagonist at postsynaptic dopamine $\mathrm{D}_{2}$ receptor, ${ }^{13}$ which was confirmed to be a dopamine $\mathrm{D}_{2}$ receptor partial agonist and gained regulatory approval as the world's first dopamine system stabilizer (DSS) in the USA.

Given that aripiprazole was reported to be associated with activation, akathisia, restlessness and insomnia shortly after its initiation; however, efforts were focused on overcoming this drawback through acquisition of lower intrinsic activity at dopamine $\mathrm{D}_{2}$ receptor than aripiprazole and serotonin $5-\mathrm{HT}_{2 \mathrm{~A}}$ receptor-antagonistic properties as seen in serotonin-dopamine antagonists (SDAs) (eg, risperidone).

Through extensive research for an effective antipsychotic with fewer side effects than other antipsychotics, brexpiprazole, a novel compound, was found to have a unique profile that captures the above-mentioned properties. Brexpiprazole is characterized as having equally high affinity for serotonin $5-\mathrm{HT}_{1 \mathrm{~A}, 2 \mathrm{~A}}$ and dopamine $\mathrm{D}_{2}$ receptors (Table 1) and lower intrinsic activity at dopamine $\mathrm{D}_{2}$ receptor than aripiprazole. ${ }^{14}$ It was thought likely that brexpiprazole may be associated with less akathisia, insomnia or restlessness due to these pharmacological properties. Brexpiprazole was assumed to act simultaneously as a partial agonist at serotonin $5-\mathrm{HT}_{1 \mathrm{~A}}$ receptor, an antagonist at serotonin $5-\mathrm{HT}_{2 \mathrm{~A}}$ receptor, and an optimally partial agonist at dopamine $\mathrm{D}_{2}$ receptor ${ }^{14,15}$ (Table 1). In animal experiments, indeed, brexpiprazole was shown to be associated with apomorphine-induced locomotive activity or stereotypy suggestive of improvements in positive symptoms of schizophrenia; it was also shown to be associated with improvements in a conditioned avoidance response model predicting the effect of positive symptoms. Furthermore, in experiments using rodents, brexpiprazole was shown to be not only associated with improved 
Table I Binding Affinity of Antipsychotics for Human Neurotransmitter Receptors (in vitro) (Ki Value)

\begin{tabular}{|c|c|c|c|c|c|c|c|c|c|c|c|c|}
\hline & BRX & APZ & OLZ & QTP & RIS & PAL & ASN & LUR & CAR & AMI & LUM & HAL \\
\hline $\mathrm{D}_{2}$ & 0.30 & 0.34 & $\mathrm{II} *$ & 180 & 2.2 & 6.6 & 1.26 & $1.68^{*}$ & 0.49 & 3 & 32 & 1.4 \\
\hline$D_{3}$ & I.I & 0.8 & 16 & 940 & 9.6 & 7.5 & 0.42 & - & 0.085 & 3.5 & - & 2.5 \\
\hline $5-\mathrm{HT}_{1 \mathrm{~A}}$ & 0.12 & 1.7 & $>1000 *$ & 230 & 210 & 1030 & 2.51 & $6.75^{*}$ & 2.6 & $>10,000$ & - & 3600 \\
\hline $5-\mathrm{HT}_{2 \mathrm{~A}}$ & 0.47 & 3.4 & 2.5 & 220 & 0.29 & 0.83 & 0.071 & $2.03 *$ & 18.8 & 8304 & 0.54 & 120 \\
\hline $5-\mathrm{HT}_{2 \mathrm{C}}$ & 34 & 15 & 28.6 & 1400 & 10 & 19.0 & 0.035 & - & 134 & $>10,000$ & - & 4700 \\
\hline $5-\mathrm{HT}_{7}$ & 3.7 & 39 & $104 *$ & 1800 & 3.0 & 6.8 & 0.12 & 0.495 & - & 11.5 & - & 1100 \\
\hline$\alpha_{1}$ & $3.8^{\#}$ & $57^{*}$ & $19 *$ & 15 & 1.4 & $11.0^{\#}$ & $1.17^{\#}$ & $47.9 *$ & $155^{\#}$ & $>10,000^{\#}$ & 73 & 4.7 \\
\hline $\mathrm{H}_{1}$ & 19 & 61 & $7^{*}$ & 8.7 & 19 & 34 & 1.00 & $>1000$ & 23.2 & $>10,000$ & $>1000$ & 440 \\
\hline$M_{1}$ & $>1000$ & 6800 & $1.9^{*}$ & 100 & 2800 & $>10,000$ & 8130 & $>1000 *$ & $>1000$ & $>10,000$ & $>1000$ & 1600 \\
\hline
\end{tabular}

Notes: *Rat data; ${ }^{*} \alpha_{1 \mathrm{~A}}$ receptor.

Abbreviations: BRX, brexpiprazole; APZ, aripiprazole; OLZ, olanzapine; QTP, quetiapine; PAL, paliperidone; ASN, asenapine; LUR, lurasidone; CAR, cariprazine; AMI, amisulpride; LUM lumateperone; HAL, haloperidol.

cognitive function; ${ }^{16}$ it was also shown to be less likely to evoke dopamine $D_{2}$ receptor supersensitivity in rats after repeated administration and likely to improve hypersensitivity associated with the use of a full dopamine $\mathrm{D}_{2}$ receptor in rats. ${ }^{10}$

\section{Efficacy and Safety}

\section{A Summary of Placebo-Controlled}

Randomized Trials in Patients with

\section{Schizophrenia}

Efficacy

\section{Short-Term Studies}

To date, three randomized, double-blind, placebocontrolled trials (RCTs) of brexpiprazole have been conducted in patients with schizophrenia (Table 2). ${ }^{11,17-29}$ Of these, two Phase III RCTs comparing brexpiprazole $2 \mathrm{mg} /$ day, $4 \mathrm{mg} /$ day and placebo were included in a pooled analysis conducted by Correll et al, ${ }^{17}$ which demonstrated that the mean change from baseline in the Positive and Negative Syndrome Scale (PANSS) total score was significantly different at -18.79 and $-20.01(P=0.0004$ and $P<0.0001)$, respectively, in those receiving brexpiprazole $2 \mathrm{mg} /$ day ( $\mathrm{n}=$ $359)$ and $4 \mathrm{mg} /$ day $(\mathrm{n}=359)$, compared to -13.3 in those receiving placebo $(n=358)$. It was also demonstrated that the positive subscale was significantly improved at -6.06 and $-6.76(P=0.0107$ and $P<0.0001)$, respectively, in those receiving brexpiprazole $2 \mathrm{mg} /$ day and $4 \mathrm{mg}$ /day, compared to -4.74 in those receiving placebo, with the negative subscale score being also significantly improved at -3.51 and $-3.59(P=0.0015$ and $P=0.0007)$, respectively, compared to -2.31 in those receiving placebo. There was a significant improvement in the Clinical Global Impression-Severity (CGI-S) score in those receiving brexpiprazole $2 \mathrm{mg}$ and $4 \mathrm{mg}(-1.07, P=0.0035$ and $-1.20, P<0.0001)$, compared to that in those receiving placebo ( -0.82$)$. Additionally, brexpiprazole was shown to improve social and personal functioning on the Personal and Social Performance Scale (PSP), with significant improvements in socially useful activities $(P<0.01)$, relationships $(P<0.01)$, self-care $(P<0.001)$, and disturbing and aggressive behavior $(P<0.05)$ in those receiving brexpiprazole compared to those receiving placebo.

The third phase III study of brexpiprazole was a 6-week, flexible-dose placebo-controlled study with an active reference (quetiapine extended release; XR). ${ }^{22}$ The mean change from baseline in the PANSS total score was -20.0 in those receiving brexpiprazole $(\mathrm{n}=150)$ compared with -14.9 in those receiving placebo $(\mathrm{n}=159)(P=0.056)$. However, the mean change from baseline in the PANSS total score was -24.0 in those receiving quetiapine XR $(n=150)$ and was statistically significantly different from that in those receiving placebo $(P<0.001)$, which validated the study methodology. It was also demonstrated that the mean change from baseline in CGI-S score was significantly improved at -0.9 , -1.2 and -1.4 in those receiving placebo, brexpiprazole, and quetiapine $\mathrm{XR}$, respectively.

Of note here also is a pooled analysis conducted by Marder et al, ${ }^{18}$ which included a further randomized controlled trial for analysis and demonstrated that the PANSS total score was significantly improved at week 6 at 20.1 in those receiving brexpiprazole, irrespective of its dose $(n=868)$, compared to 14.3 in those receiving placebo $(\mathrm{n}=517)(P<0.0001)$.

Another study of interest, pending validation of its results, is a randomized, double-blind, placebo-controlled study conducted to evaluate brexpiprazole 1, 2 and $4 \mathrm{mg} /$ day in Japanese patients with schizophrenia requiring hospitalization for acute relapse of disease $(n=459) .{ }^{19}$ In this 
Table 2 Clinical Trials of Brexpiprazole in Schizophrenia

\begin{tabular}{|c|c|c|c|c|c|c|}
\hline $\begin{array}{l}\text { Authors } \\
\text { (Reference) }\end{array}$ & $\begin{array}{l}\text { Duration } \\
\text { (Weeks) }\end{array}$ & Disease Type & N Randomized & $\begin{array}{l}\text { Brexpiprazole } \\
\text { Dose (n) }\end{array}$ & $\begin{array}{l}\text { Comparator } \\
\text { (n) }\end{array}$ & Comments \\
\hline \multicolumn{7}{|c|}{ Pooled/meta-analyses } \\
\hline Correll et al ${ }^{17}$ & 6 & $\begin{array}{l}\text { Acute } \\
\text { schizophrenia }\end{array}$ & & $\begin{array}{l}0.25 \text { mg (90), } \\
\text { I mg (I20), } \\
2 \text { mg (368), } \\
4 \text { mg (364) }\end{array}$ & Placebo (368) & $\begin{array}{l}\text { Pooled analysis of } 3 \text { randomized, } \\
\text { double-blind, placebo-controlled } \\
\text { studies. } \\
\text { Brexpiprazole } 2 \mathrm{mg} \text { and } 4 \mathrm{mg} \text { were } \\
\text { superior to placebo in efficacy } \\
\text { (change in PANSS total score and } \\
\text { CGI-S) (NNT for response } \geq 30 \% \\
\text { improvements to } 2 \mathrm{mg} \text { and } 4 \mathrm{mg}, 9 \\
\text { and 6). }\end{array}$ \\
\hline Marder et $\mathrm{al}^{18}$ & 6 & $\begin{array}{l}\text { Acute } \\
\text { schizophrenia }\end{array}$ & & $\begin{array}{l}\text { Fixed/flexible } \\
\text { dose }(868)\end{array}$ & Placebo (5|7) & $\begin{array}{l}\text { Meta-analysis of } 4 \text { short- and long- } \\
\text { term studies showed a clinically } \\
\text { meaningful mean change in PANSS } \\
\text { total score of }-20.1 \text { in those } \\
\text { receiving brexpiprazole, compared } \\
\text { to } 14.3 \text { in those receiving placebo. }\end{array}$ \\
\hline \multicolumn{7}{|c|}{ Short-term studies } \\
\hline $\begin{array}{l}\text { Ishigooka } \\
\text { et } \mathrm{al}^{19}\end{array}$ & 6 & $\begin{array}{l}\text { Acute } \\
\text { schizophrenia }\end{array}$ & 459 & $\begin{array}{l}\text { I mg (II5), } 2 \mathrm{mg} \\
(I \mid 5), 4 \mathrm{mg} \\
(I \mid 3)\end{array}$ & Placebo (I16) & $\begin{array}{l}\text { Phase III multicenter, randomized, } \\
\text { double-blind, placebo-controlled } \\
\text { study in Japan. } \\
\text { Brexpiprazole at } 2 \mathrm{mg} / \text { day showed } \\
\text { statistically significant efficacy (as } \\
\text { assessed by PANSS total score) } \\
\text { compared to placebo with the most } \\
\text { common TEAE being worsening of } \\
\text { schizophrenia. }\end{array}$ \\
\hline Correll et $\mathrm{al}^{20}$ & 6 & $\begin{array}{l}\text { Acute } \\
\text { schizophrenia }\end{array}$ & 636 & $\begin{array}{l}0.25 \mathrm{mg}(90), \\
2 \mathrm{mg}(\mathrm{I} 82), \\
4 \mathrm{mg}(\mathrm{I} 80)\end{array}$ & Placebo (184) & $\begin{array}{l}\text { Phase III multicenter, randomized, } \\
\text { double-blind, placebo-controlled } \\
\text { study. } \\
\text { Brexpiprazole at } 2 \text { and } 4 \mathrm{mg} / \text { day } \\
\text { demonstrated statistically significant } \\
\text { efficacy (as assessed by PANSS total } \\
\text { score and CGI-S) compared to } \\
\text { placebo with the most common } \\
\text { TEAE being akathisia ( } 2 \mathrm{mg}, 4.4 \% \text {; } \\
4 \mathrm{mg}, 7.2 \% \text {; placebo, } 2.2 \%)\end{array}$ \\
\hline Kane et $\mathrm{al}^{21}$ & 6 & $\begin{array}{l}\text { Acute } \\
\text { schizophrenia }\end{array}$ & 674 & $\begin{array}{l}\text { I mg (I20), } \\
2 \mathrm{mg}(186), 4 \mathrm{mg} \\
(184)\end{array}$ & Placebo (184) & $\begin{array}{l}\text { Phase III multicenter, randomized, } \\
\text { double-blind, placebo-controlled } \\
\text { study. } \\
\text { Brexpiprazole } 4 \mathrm{mg} \text { showed } \\
\text { statistically significant efficacy (as } \\
\text { assessed by PANSS total score and } \\
\text { CGI-S) compared to placebo. The } \\
\text { most common TEAEs were } \\
\text { headache, insomnia and restlessness }\end{array}$ \\
\hline
\end{tabular}

(Continued) 
Table 2 (Continued).

\begin{tabular}{|c|c|c|c|c|c|c|}
\hline $\begin{array}{l}\text { Authors } \\
\text { (Reference) }\end{array}$ & $\begin{array}{l}\text { Duration } \\
\text { (Weeks) }\end{array}$ & Disease Type & N Randomized & $\begin{array}{l}\text { Brexpiprazole } \\
\text { Dose (n) }\end{array}$ & $\begin{array}{l}\text { Comparator } \\
\text { (n) }\end{array}$ & Comments \\
\hline $\begin{array}{l}\text { Citrome } \\
\text { et } \mathrm{al}^{11}\end{array}$ & 6 & $\begin{array}{l}\text { Acute } \\
\text { schizophrenia }\end{array}$ & 97 & $\begin{array}{l}\text { Target dose } 3 \mathrm{mg} \\
(\mathrm{I}-4 \mathrm{mg})(64)\end{array}$ & $\begin{array}{l}\text { Aripiprazole } \\
\text { Target dose } \\
15 \mathrm{mg} \\
(10-20 \mathrm{mg})^{32}\end{array}$ & $\begin{array}{l}\text { Phase IIlb, multicenter, randomized, } \\
\text { open-label, exploratory study. } \\
\text { Brexpiprazole showed significant } \\
\text { improvement in PANSS total score. } \\
\text { Brexpiprazole demonstrated } \\
\text { a slightly greater numerical } \\
\text { improvement compared with } \\
\text { aripiprazole in symptoms and } \\
\text { function (CGI-S, SLOF, BIS-II). The } \\
\text { incidence of akathisia was lower in } \\
\text { brexpiprazole (9.4\%) than } \\
\text { aripiprazole }(21.2 \%) \text {. }\end{array}$ \\
\hline $\begin{array}{l}\text { Van Erp } \\
\text { et } \mathrm{al}^{23}\end{array}$ & 6 & $\begin{array}{l}\text { Stable } \\
\text { schizophrenia } \\
\text { (outpatients) }\end{array}$ & 38 & $\begin{array}{l}2 \mathrm{mg}(19) \\
4 \mathrm{mg}(19)\end{array}$ & & $\begin{array}{l}\text { Exploratory, multicenter, } \\
\text { randomized, double-blind, functional } \\
\text { magnetic resonance imaging study. } \\
\text { Brexpiprazole showed a significant } \\
\text { decrease in right VLPFC BOLD } \\
\text { activation during the stop-signal task, } \\
\text { and was associated with significantly } \\
\text { improved stop-signal reaction time. } \\
\text { No worsening of psychiatric } \\
\text { symptoms, functioning, or impulsivity } \\
\text { occurred in the patients. }\end{array}$ \\
\hline Malla et $\mathrm{al}^{24}$ & 16 & $\begin{array}{l}\text { Early-episode } \\
\text { schizophrenia } \\
\text { (I8-35 years } \\
\text { old, < } 5 \text { years' } \\
\text { duration of } \\
\text { illness) }\end{array}$ & 49 & $\begin{array}{l}\text { Target dose: } \\
3 \mathrm{mg} \text { ( }-4 \mathrm{mg}) \\
\text { (49) }\end{array}$ & - & $\begin{array}{l}\text { Exploratory, open-label, flexible-dose } \\
\text { study. } \\
51 \% \text { of patients completed the study. } \\
\text { Brexpiprazole significantly improved } \\
\text { PANSS total score and social } \\
\text { functioning (PSP and SLOF) and } \\
\text { PSQI. The most common adverse } \\
\text { events were insomnia, somnolence, } \\
\text { sedation, weight increase, and } \\
\text { nausea. }\end{array}$ \\
\hline \multicolumn{7}{|c|}{ Long-term studies } \\
\hline $\begin{array}{l}\text { Fleischhacker } \\
\text { et } \mathrm{al}^{25}\end{array}$ & 52 & $\begin{array}{l}\text { Maintenance } \\
\text { treatment in } \\
\text { schizophrenia }\end{array}$ & 202 & $\mathrm{I}-4 \mathrm{mg}(97)$ & Placebo (105) & $\begin{array}{l}\text { Phase III, multicenter, randomized, } \\
\text { double-blind, placebo-controlled } \\
\text { relapse prevention study. } \\
\text { Brexpiprazole significantly delayed } \\
\text { the time to impending relapse } \\
\text { compared to placebo (HR, } 0.292 \text {; } \\
95 \% \mathrm{Cl}, 0.156-0.548 \text { ) (relapse rates: } \\
\text { brexpiprazole, I3.5\%; placebo, } \\
38.5 \% \text { ) with the most common } \\
\text { TEAEs being headache, and insomnia. }\end{array}$ \\
\hline
\end{tabular}

(Continued) 
Table 2 (Continued).

\begin{tabular}{|c|c|c|c|c|c|c|}
\hline $\begin{array}{l}\text { Authors } \\
\text { (Reference) }\end{array}$ & $\begin{array}{l}\text { Duration } \\
\text { (Weeks) }\end{array}$ & Disease Type & N Randomized & $\begin{array}{l}\text { Brexpiprazole } \\
\text { Dose (n) }\end{array}$ & $\begin{array}{l}\text { Comparator } \\
\text { (n) }\end{array}$ & Comments \\
\hline Forbes et $\mathrm{al}^{26}$ & 52 & $\begin{array}{l}\text { Maintenance } \\
\text { treatment in } \\
\text { schizophrenia } \\
\text { (outpatients) }\end{array}$ & $\begin{array}{l}\text { I072: } \\
257 \text { de novo } \\
815 \text { rollover }\end{array}$ & $\mathrm{I}-4 \mathrm{mg}(\mathrm{I044})$ & - & $\begin{array}{l}\text { Phase } 3 \text { multicenter, long-term, } \\
\text { open-label study. } \\
47.4 \% \text { of patients completed the } \\
\text { study and } 14.6 \% \text { discontinued due to } \\
\text { TEAEs (the most common TEAEs, } \\
\text { schizophrenia, insomnia and weight } \\
\text { gain). The symptoms and functioning } \\
\text { showed continual improvement. }\end{array}$ \\
\hline $\begin{array}{l}\text { Ishigooka } \\
\text { et } \mathrm{al}^{27}\end{array}$ & 52 & $\begin{array}{l}\text { Maintenance } \\
\text { treatment in } \\
\text { schizophrenia }\end{array}$ & $\begin{array}{l}282: \\
184 \text { de novo } \\
98 \text { rollover }\end{array}$ & $\mathrm{I}-4 \mathrm{mg}(282)$ & - & $\begin{array}{l}\text { Phase III multicenter, long-term, } \\
\text { open-label study. } \\
53.2 \% \text { of patients completed the } \\
\text { study. The most common TEAEs } \\
\text { were nasopharyngitis and worsening } \\
\text { of schizophrenia. PANSS total and } \\
\text { CGI-S remained stable until week } 52 \text {. }\end{array}$ \\
\hline \multicolumn{7}{|c|}{ Retrospective studies } \\
\hline $\begin{array}{l}\text { Yoshimura } \\
\text { et } \mathrm{al}^{28}\end{array}$ & 16 & $\begin{array}{l}\text { Schizophrenia/ } \\
\text { Schizoaffective } \\
\text { disorder }\end{array}$ & 120 & $\begin{array}{l}\text { LAT (98) } \\
\text { HAT (22) }\end{array}$ & & $\begin{array}{l}\text { A retrospective survey of all } \\
\text { inpatients and outpatients. } \\
\text { Previous high-dose antipsychotic } \\
\text { therapy (Chlorpromazine-equivalent } \\
\text { doses }>800 \mathrm{mg} \text { ) is an independent } \\
\text { risk factor for brexpiprazole } \\
\text { discontinuation in patients with } \\
\text { schizophrenia or schizoaffective } \\
\text { disorder. }\end{array}$ \\
\hline Yan et $\mathrm{al}^{29}$ & $\begin{array}{l}\geq 52 \\
\text { Follow-up }\end{array}$ & Schizophrenia & 6254 & 176 & $\begin{array}{l}\text { Ziprasidone } \\
(391) \\
\text { Paliperidone } \\
(453) \\
\text { Lurasidone } \\
\text { (523) } \\
\text { Aripiprazole } \\
\text { (786) } \\
\text { Quetiapine } \\
\text { (1234) } \\
\text { Olanzapine } \\
\text { (1264) }\end{array}$ & $\begin{array}{l}\text { Retrospective cohort study. } \\
\text { Brexpiprazole users had the lowest } \\
\text { mean psychiatric costs among all oral } \\
\text { atypical antipsychotic users } \\
(\$ 12,013) \text {. Compared with } \\
\text { brexpiprazole users, paliperidone } \\
\text { and quetiapine users had more } \\
\text { psychiatric hospitalizations per year. } \\
\text { Paliperidone had higher psychiatric } \\
\text { costs than brexpiprazole (total, } \\
\text { medical). Psychiatric medical costs } \\
\text { were also higher in olanzapine users } \\
\text { than in brexpiprazole users. }\end{array}$ \\
\hline
\end{tabular}

Abbreviations: PANSS, Positive and Negative Syndrome Scale; CGI-S, Clinical Global Impression-Severity; NNT, number needed to treatment; TEAE, treatment-emergent adverse event; HR, hazard ratio; SLOF, Specific Levels of Functioning Scale; BIS, Barratt Impulsiveness Scale, PSP, Personal and Social Performance Scale; PSQI, Pittsburgh Sleep Quality Index; VLPFC, ventrolateral prefrontal cortex; BOLD, blood oxygen level-dependent; LAT, previous low-dose antipsychotic therapy; HAT, previous high-dose antipsychotic therapy.

study, the difference (95\% confidence interval [CI]) in PANSS total score at week 6 was shown to be statistically significant at $-7.32(-13.04,-1.59)(P=0.0124)$ between those receiving brexpiprazole $2 \mathrm{mg} /$ day and placebo, albeit non-significant at $-0.63(-6.50,5.24)$ and $-3.86(-9.71$,
2.00), respectively, between those receiving brexpiprazole $1 \mathrm{mg} /$ day and placebo and between those receiving brexpiprazole $4 \mathrm{mg}$ /day and placebo. The latter results are thought likely to be due to a history of high-dose polypharmacy among the patients that could have affected the efficacy 
assessment of brexpiprazole in the study, given that those without prior high-dose polypharmacy receiving brexpiprazole $4 \mathrm{mg}$ /day were associated with a significant reduction in PANSS total score compared to those receiving placebo $(P<0.05)$, suggesting that brexpiprazole $4 \mathrm{mg}$ /day was effective in those without a prior history of high-dose polypharmacy (Table 3). According to a survey on Asian prescription patterns on antipsychotics, the proportion of patients receiving antipsychotic polypharmacy or overdose was shown to be considerably higher in Japan than in other Asian countries. ${ }^{30}$

\section{Long-Term Studies}

Brexpiprazole has also been evaluated for its long-term efficacy as a maintenance treatment for schizophrenia. In a randomized, double-blind trial, Fleischhacker et al assigned patients with schizophrenia to brexpiprazole (at a flexible dose ranging from 1 to $4 \mathrm{mg} /$ day; mean dosage, $3.6 \mathrm{mg} /$ day) or to placebo to evaluate the efficacy of brexpiprazole in preventing relapses. ${ }^{25}$ This study has demonstrated that those receiving brexpiprazole had a significantly longer time to relapse $(P<0.0001)$, with the hazard ratio (HR) $(95 \% \mathrm{CI})$ being $0.292(0.156,0.548)$ versus placebo, and that those receiving brexpiprazole were associated with a significantly lower relapse rate at $13.5 \%$ compared to $38.5 \%$ in those receiving placebo $(P<0.0001)$.

In a 52-week, open-label study, Forbes et al included a total of 1072 patients who had participated in 3 short-term, randomized, double-blind, placebo-controlled trials, as well as de novo patients who had not been part of these trials, to evaluate the safety and tolerability of brexpiprazole. ${ }^{26}$ In this study, the efficacy assessment was also conducted as a secondary endpoint in 410 patients, and demonstrated that the PANSS total score improved by 12.2 points. In addition, the CGI-S score was improved by a mean of 0.6 with the severity of disease improved from mild-tomoderate to mild in those receiving brexpiprazole (with its dose allowed to be flexible and range from 1 to $4 \mathrm{mg} /$ day), and the PSP total score was also improved by 7.7 points. It has also demonstrated improvements in patients rolled over from previous phase III trials, as well as in patients newly receiving brexpiprazole (de novo).

Likewise, a 52-week, open-label study conducted by Ishigooka et al included patients with schizophrenia rolled

Table 3 Mean Change at Week 6 in PANSS Total Score from Baseline in Patients with or without Prior History of Polypharmacy ${ }^{19}$

\begin{tabular}{|c|c|c|c|c|c|c|c|c|c|}
\hline & \multirow[t]{3}{*}{ Group } & \multicolumn{8}{|c|}{ PANSS Total Score } \\
\hline & & \multicolumn{3}{|c|}{ Baseline Score } & \multicolumn{3}{|c|}{$\begin{array}{l}\text { Change from } \\
\text { Baseline }\end{array}$} & \multicolumn{2}{|l|}{ Treatment Difference } \\
\hline & & $\mathbf{n}$ & Mean & SD & $\mathbf{n}$ & $\begin{array}{l}\text { LS } \\
\text { Mean }\end{array}$ & SD & $\begin{array}{l}\text { Difference from } \\
\text { Placebo }(95 \% \mathrm{Cl})\end{array}$ & $P$ value \\
\hline \multirow{4}{*}{$\begin{array}{l}\text { Patients without prior history of } \\
\text { polypharmacy }\end{array}$} & Placebo & 106 & 96.22 & $|8.5|$ & 67 & -7.44 & 2.13 & & \\
\hline & $\begin{array}{l}\text { Brexpiprazole } \\
\text { I mg }\end{array}$ & 103 & 98.86 & 20.17 & 67 & -7.66 & 2.15 & $-0.22(-6.20,5.76)$ & 0.942 \\
\hline & $\begin{array}{l}\text { Brexpiprazole } \\
2 \mathrm{mg}\end{array}$ & 106 & 98.68 & 19.44 & 76 & -15.16 & 2.03 & $-7.72(-13.52,-1.92)$ & 0.009 \\
\hline & $\begin{array}{l}\text { Brexpiprazole } \\
4 \mathrm{mg}\end{array}$ & 97 & 96.58 & 15.46 & 64 & -13.64 & 2.18 & $-6.21(-12.22,-0.19)$ & 0.043 \\
\hline \multirow{4}{*}{$\begin{array}{l}\text { Patients with prior history of } \\
\text { polypharmacy }\end{array}$} & Placebo & 7 & 111.86 & 25.84 & 3 & 2.41 & 16.74 & & \\
\hline & $\begin{array}{l}\text { Brexpiprazole } \\
\text { l mg }\end{array}$ & 9 & 103.78 & 26.37 & 6 & -11.93 & 9.60 & $-14.34(-6-0.16,31.49)$ & 0.465 \\
\hline & $\begin{array}{l}\text { Brexpiprazole } \\
2 \mathrm{mg}\end{array}$ & 7 & 94.57 & 16.21 & 5 & -10.45 & 10.23 & $-12.86(-63.42,37.70)$ & 0.548 \\
\hline & $\begin{array}{l}\text { Brexpiprazole } \\
4 \mathrm{mg}\end{array}$ & 12 & 94.92 & 18.48 & 4 & 7.75 & 14.02 & $5.34(-49.86,60.55)$ & 0.824 \\
\hline
\end{tabular}

Notes: Polypharmacy, defined as administration of $\geq 3$ antipsychotics with a mean total chlorpromazine (CP)-equivalent dose of $\geq 1000 \mathrm{mg} /$ day or administration of $\geq 3$ antipsychotics with $\geq 2$ antipsychotics having a CP-equivalent dose of $\geq 600 \mathrm{mg} / \mathrm{day}$, from 30 days prior to informed consent to the day before hospital admission. 
over from previous short-term studies conducted in Japan, as well as new (de novo) patients with schizophrenia switching to brexpiprazole from previous antipsychotics, to evaluate the safety and tolerability of brexpiprazole (with its dose allowed to be flexible and range from 1 to $4 \mathrm{mg} /$ day). ${ }^{27}$ With the mean change in PANSS total score at week 52 shown to be -7.0 in de novo patients and -9.4 in rolled over patients and with the CGI-S and the PANSS subscale scores shown to remain stable for up to week 52, this study clearly demonstrated the long-term efficacy of brexpiprazole not only in patients rolled over from previous trials but also in de novo patients.

\section{Safety}

\section{Short-Term Studies}

Kane et al conducted a pooled analysis of randomized, double-blind, placebo-controlled studies of brexpiprazole published to date with a focus on its adverse effect profile, ${ }^{31}$ which demonstrated that, of all the treatmentemergent adverse events (TEAEs) reported in $\geq 5 \%$ of patients receiving brexpiprazole $\leq 4 \mathrm{mg} /$ day $(\mathrm{n}=1163)$, none occurred twice or more often in those receiving placebo $(n=463)$ and that akathisia occurred in a small proportion $(5.8 \%)$ of those receiving brexpiprazole (compared to $4.5 \%$ of those receiving placebo) early with its incidence shown to peak 8-11 days after initiation of brexpiprazole.

Weiss et al conducted a pooled analysis of the effects of brexpiprazole versus placebo on weight gain ${ }^{32}$ and demonstrated a weight gain at week 6 of $1.2 \mathrm{~kg}$ in those receiving brexpiprazole 2 or $4 \mathrm{mg} /$ day $(\mathrm{n}=724)$ versus $0.2 \mathrm{~kg}$ in those receiving placebo $(\mathrm{n}=362)$.

In addition, the proportion of patients whose body weight increased by at least $7 \%$ while on brexpiprazole 2 or $4 \mathrm{mg} /$ day and placebo were $10.4 \%$ and $4.1 \%$, respectively.

It is also of interest that Ivkovic et al conducted a pooled analysis of the effect of brexpiprazole on prolactin, ${ }^{9}$ demonstrating, among those with normal prolactin levels at baseline, a mean change in prolactin levels at week 6 of $6.72 \mathrm{ng} / \mathrm{mL}$ and $2.35 \mathrm{ng} / \mathrm{mL}$ in women $(\mathrm{n}=$ $195)$ and men $(n=267)$ receiving brexpiprazole $2-4 \mathrm{mg} /$ day, respectively, as compared to $0.08 \mathrm{ng} / \mathrm{mL}$ in women ( $\mathrm{n}$ $=98)$ and $0.66 \mathrm{ng} / \mathrm{mL}$ in men $(\mathrm{n}=158)$ receiving placebo, respectively. Among those whose prolactin levels were shown to be above the upper limit of normal at baseline, the study revealed a mean change in prolactin levels at week 6 of -33.41 and $-12.64 \mathrm{ng} / \mathrm{mL}$ in women $(\mathrm{n}=47)$ and men $(\mathrm{n}=95)$ receiving brexpiprazole $2-4 \mathrm{mg} / \mathrm{day}$, respectively, as compared to -38.79 and $-11.29 \mathrm{ng} / \mathrm{mL}$ in women $(n=26)$ and men $(n=49)$ receiving placebo, concluding that brexpiprazole affects prolactin levels only minimally.

In the short-term study of brexpiprazole by Ishigooka et al mentioned earlier ${ }^{19}$ (Table 2), of note, the incidence of TEAEs was shown to be $70.4 \%, 69.3 \%$, and $65.5 \%$ in those receiving brexpiprazole $1 \mathrm{mg}, 2 \mathrm{mg}$ and $4 \mathrm{mg} /$ day, respectively, as compared to $76.7 \%$ in those receiving placebo. Of these, the TEAEs reported in $\geq 5 \%$ of the patients receiving brexpiprazole and twice or more often than in those receiving placebo were vomiting, elevated blood prolactin, diarrhea, nausea, and dental caries and were mild to moderate in severity in most cases. The mean change in body weight in this study was shown to be $-0.67,-0.04$, and $-0.50 \mathrm{~kg}$ in those receiving brexpiprazole $1 \mathrm{mg}, 2 \mathrm{mg}$ and $4 \mathrm{mg} /$ day, respectively, as compared to $-1.16 \mathrm{~kg}$ in those receiving placebo. Additionally, the proportions of patients who had a clinically relevant gain in body weight $(\geq 7 \%)$ were $4.3 \%, 5.3 \%, 2.7 \%$ and $0.9 \%$ in the brexpiprazole $1,2,4 \mathrm{mg} /$ day and placebo group, respectively. Furthermore, the incidence of akathisia was quite low in those receiving brexpiprazole, with its occurrence shown to be highest in the first 3 weeks after initiation of the drug. Finally, no major change was noted from baseline in laboratory parameters, vital signs, ECG and other parameters in those receiving brexpiprazole.

\section{Long-Term Studies}

In the long-term treatment of schizophrenia with any antipsychotic, how it may affect body weight, existing metabolic syndrome or dyskinesia becomes of particular interest.

In the relapse prevention trial conducted by Fleischhacker et al described above ${ }^{25}$ (Table 2), the incidence of TEAEs was shown to be $43.3 \%$ in those receiving brexpiprazole $1-4 \mathrm{mg} /$ day $(\mathrm{n}=97)$ as compared to $55.8 \%$ in those receiving placebo $(n=104)$, with the incidence of TEAEs leading to treatment discontinuation being $5.2 \%$ in those receiving brexpiprazole compared to $11.5 \%$ in those receiving placebo; no TEAEs, including akathisia and weight gain, occurred twice or more frequently in those receiving brexpiprazole than in those receiving placebo. Again, in the maintenance phase of treatment, the study revealed a mean change in body weight of $-0.3 \mathrm{~kg}$ in those receiving brexpiprazole, as compared to $-2.2 \mathrm{~kg}$ in those receiving placebo, while the two groups were shown to be comparable with regard to the extrapyramidal symptoms (EPS), glucose/lipid metabolism, 
and heart rate-corrected QT interval (QTc) parameters, with no tardive dyskinesia seen in those receiving brexpiprazole.

In the prospective, open-label study conducted by Forbes et $\mathrm{al}^{26}$ also described above (Table 2), the incidence of TEAEs was shown to be $60.4 \%$ in those receiving brexpiprazole at flexible doses ranging between 1 and $4 \mathrm{mg}(\mathrm{n}=1031)$, with the incidence of TEAEs leading to study discontinuation being $14.6 \%$. The TEAEs reported in $\geq 5 \%$ of patients receiving brexpiprazole included worsening of schizophrenia (11.6\%), insomnia (8.6\%), weight gain $(7.8 \%)$, headache $(6.4 \%)$, and agitation $(5.4 \%)$, with the change in body weight from baseline being $1.3 \mathrm{~kg}$ at week $26(\mathrm{n}=611)$ and $2.1 \mathrm{~kg}$ at week $52(\mathrm{n}=408)$. Thus, the authors concluded that no unforeseeable safety or tolerability issues were found and that brexpiprazole has a highly favorable tolerability profile.

During the course of this prospective, open-label, longterm study, ${ }^{26}$ Newcomer et al focused attention on fasting metabolic parameters and investigated how the 52-week treatment with brexpiprazole might affect the trial subjects classified into normal, borderline, and high lipid/glucose categories, ${ }^{33}$ demonstrating that those exhibiting an unfavorable shift ("normal to borderline or high" or "borderline to high") accounted for a smaller proportion than those exhibiting a favorable shift ("borderline or high to normal" or "high to normal").

Thus, overall, both short- and long-term safety results demonstrate that brexpiprazole is associated with a low incidence of akathisia and affects glucose/lipid metabolism only minimally. Brexpiprazole is also shown to have a minimal effect on QTc. In conclusion, brexpiprazole is deemed a safe antipsychotic, consistently with the results of the above-mentioned network meta-analysis. ${ }^{6}$

\section{Summary of Other Studies of Interest \\ Exploratory Studies}

Citrome et al conducted a randomized, open-label trial comparing the efficacy and safety of brexpiprazole $3 \mathrm{mg} /$ day versus aripiprazole $15 \mathrm{mg} /$ day $^{11}$ (Table 2), and demonstrated that the mean change from baseline in PANSS total score at week 6 (primary outcome measure) was significantly different at -22.9 and -19.4 points in patients receiving brexpiprazole $(n=64)$ and aripiprazole $(n=33)$, respectively, and that the rate of response at week 6 (a reduction of $\geq 30 \%$ from baseline in PANSS total score or a Clinical Global Impressions-Improvement Scale [CGI-I] score of 1 or 2) was higher at $60.9 \%$ in those receiving brexpiprazole than in those receiving aripiprazole (48.5\%). The study also showed that the mean change from baseline at week 6 in the Barratt Impulsive Scale-11 item (BIS-11) as a measure of impulsivity was shown to be slightly decreased at -2.7 in those receiving brexpiprazole, but not decreased at 0.1 in those receiving aripiprazole. Furthermore, the Specific Levels of Functioning Scale (SLOF) were shown to be significantly improved at week 6 in those receiving brexpiprazole, with improvements from baseline shown in all four of the SLOF subscales (ie, interpersonal relationships, social acceptability, activities, and work skills) in those receiving brexpiprazole versus two of the SLOF subscales (ie, activities and work skills) in those receiving aripiprazole. Also, while those receiving brexpiprazole was not associated with worsening of cognitive function on any of the cognitive tests, those receiving aripiprazole were shown to have fared worse on the Two-Back Memory Task, of all cognitive tests performed. In addition, the incidence of TEAEs in those receiving brexpiprazole and aripiprazole was $57.8 \%$ and $63.6 \%$, respectively, with the incidence of akathisia in those receiving brexpiprazole shown to be $9.4 \%$, less than half that in those receiving aripiprazole $(21.2 \%)$.

Again, of note, an exploratory, open-label study of brexpiprazole at a flexible dose (1-4 mg/day with the target dose being $3 \mathrm{mg}$ /day) has been conducted in a total of 49 patients aged 18 to 35 years old who developed early-episode schizophrenia within the last 5 years ${ }^{24}$ (Table 2), which demonstrated that the mean change in PANSS total score at week 16 (primary outcome measure) was -10.2 in these early-episode patients, with significant improvements seen from week 1 versus baseline and with these improvements sustained until week 16. Also, significant improvements from baseline were observed in these patients at week 16 in CGI-S, SLOF, PSP, Pittsburg Sleep Quality Index (PSQI), and 14-item Treatment Satisfaction Questionnaire for Medication (TSQM). TEAEs were reported to have occurred in $57.1 \%$ of the patients, with those reported in $\geq 5 \%$ of the patients being insomnia $(14.3 \%)$, somnolence $(8.2 \%)$, sedation, weight gain, and nausea $(6.1 \%$ each), demonstrating that brexpiprazole is well tolerated in this particular population.

Furthermore, van Erp et al conducted a randomized, double-blind, functional magnetic resonance imaging (fMRI) study to investigate the effect of brexpiprazole on brain regions involved in controlling impulsive behavior. ${ }^{23}$ This study has demonstrated that 6 weeks of treatment 
with brexpiprazole significantly reduced blood oxygenlevel dependent (BOLD) activation in the right ventrolateral prefrontal cortex (VLPFC) during performance of tasks associated with control of impulsivity $(P=0.0053)$ as well as in stop-signal reaction time (SSRT) $(P=$ 0.0050), with no worsening of psychiatric symptoms, functioning or impulsivity. These findings appear to provide preliminary support for the clinical use of brexpiprazole, given that impulsivity in schizophrenia represents a risk factor for suicide, drug abuse, and other risktaking behaviors.

\section{Switching Patients with Acute Schizophrenia to Brexpiprazole Monotherapy}

Correll et $\mathrm{al}^{34}$ conducted a study to compare different antipsychotic cross-titration schedules for their tolerability and efficacy in patients switched to brexpiprazole monotherapy from another antipsychotic during a conversion phase $(n=404)$ in the relapse prevention study of Fleischhacker et al described above. ${ }^{25}$ Patients who had thus completed switching to brexpiprazole monotherapy were classified according to the physician-determined switching periods into those having converted over 1 to 7 days, 8 to 14 days, 15 to 21 days, and 22 to 33 days and were subjected to a post hoc analysis 8 weeks after switching. Of the entire 404 patients, $72.0 \%$ were found to have converted over 22 to 33 days. Of the 292 patients who had successfully switched and completed 8 weeks of treatment with brexpiprazole, $80.1 \%$ required 22 to 33 days in the conversion phase, followed by 15 to 21 days (11.0\%), 8 to 14 days $(6.5 \%)$, and 1 to 7 days $(2.4 \%)$. The proportion of patients discontinuing treatment due to unsatisfactory response or intolerability due to AEs was shown to be consistently small in all conversion groups and not different between the conversion groups, while the incidence of TEAEs was lowest at $44.4 \%$ in those having converted over 22 to 33 days, compared to $71.4 \%$ in those having converted over 1 to 7 days, $84.2 \%$ in those having converted over 8 to 14 days, and $62.5 \%$ in those having converted over 15 to 21 days. These findings altogether suggest that the longer their switching periods, the more likely patients are to complete switching successfully.

Another study, pending validation of its findings, is a retrospective study conducted by Yoshimura et $\mathrm{al}^{28}$ in an attempt to determine continuation rates in patients with schizophrenia during 16 weeks of treatment with brexpiprazole as well as to identify predictors of brexpiprazole discontinuation. Of the 120 patients included in this study, 52 (43.4\%) discontinued treatment with brexpiprazole for reasons including unsatisfactory response $(\mathrm{n}=32)$ and intolerability due to AEs $(n=8)$. The continuation rate was shown to be significantly low among those who had previously received high-dose antipsychotic therapy (defined as a CP-equivalent dose of $>800 \mathrm{mg}$ ) than among those who had previously received lower-dose antipsychotic therapy (a CP-equivalent dose of $\leq 800 \mathrm{mg}$ ). Indeed, multivariate analysis (Cox regression analysis) identified a CP-equivalent dose of $>800 \mathrm{mg}$ in prior antipsychotics as a factor associated with brexpiprazole discontinuation in this study. Again, unlike in Western countries, patients with schizophrenia-receiving polypharmacy who account for a high proportion of all patients treated for schizophrenia in Japan ${ }^{19,28}$ may be deemed treatmentresistant. These considerations need to be taken into account when considering converting patients with schizophrenia to brexpiprazole from any other antipsychotic.

\section{Database Studies}

Yan et $\mathrm{al}^{29}$ conducted a retrospective, real-world cohort study to compare all-cause and psychiatric hospitalization and medical costs in patients newly treated with brexpiprazole versus other atypical antipsychotics by drawing on the available US insurance claims data. This study has demonstrated that all-cause total costs and all-cause medical costs did not differ across atypical antipsychotic groups; however, patients treated with brexpiprazole had the lowest mean psychiatric costs of all patients prescribed atypical antipsychotics (Table 2).

\section{Clinical Experience with Brexpiprazole at a Psychiatric Clinic in Japan}

In an attempt to provide insight into the real-world efficacy of brexpiprazole in clinical practice, a retrospective medical record review was conducted at Himorogi Clinic, Tokyo, Japan. This review included outpatients treated with brexpiprazole at the clinic between April 2018 and April 2020. This study was approved by the Institutional Review Board of Himorogi Clinic and all patients (parents/guardians for patients under the age of 18) provided written informed consent prior to study initiation.

A total of 94 patients were included in this study and a summary of the patient demographics is shown in Table 4. 
Table 4 Patient Demographics $(n=94)$

\begin{tabular}{|l|l|l|l|}
\hline \multicolumn{2}{|l|}{} & n & $\%$ \\
\hline Sex & Male & 50 & 53 \\
& Female & 44 & 47 \\
\hline Age & $<20$ & 2 & 2 \\
(years) Mean \pm SD: $42.2 \pm 14.7$ & $20-29$ & 23 & 24 \\
years old & $30-39$ & 16 & 17 \\
& $40-49$ & 24 & 26 \\
& $50-59$ & 15 & 16 \\
& $60-69$ & 12 & 13 \\
& $70-79$ & 2 & 2 \\
\hline Duration of illness (years) & $<5$ & 28 & 30 \\
Mean \pm SD: I5.3 \pm I2.7 years & $5 \leq /<10$ & 17 & 18 \\
& $10 \leq /<20$ & 19 & 20 \\
& $20 \leq /<30$ & 17 & 18 \\
& $30 \leq /<55$ & 13 & 14 \\
\hline CGI-S & Normal & 0 & 0 \\
Mean \pm SD: $5.25 \pm 0.65$ & Borderline mentally ill & 0 & 0 \\
& Mildly ill & 0 & 0 \\
& Moderately ill & 9 & 10 \\
& Markedly ill & 54 & 57 \\
& Severely ill & 29 & 31 \\
& Among the most & 2 & 2 \\
& extremely ill & & \\
\hline
\end{tabular}

Abbreviation: CGI-S, Clinical Global Impression-Severity.

At week 8 following initiation of brexpiprazole, $66.0 \%$ of the patients $(n=62)$ remained on brexpiprazole with the mean CGI-S score significantly decreased to 3.7 from baseline (5.4), demonstrating improvements in disease severity.

Reasons for discontinuation included lack of efficacy $(\mathrm{n}=5)$, AEs $(\mathrm{n}=12)$ (drowsiness, 3 ; headache, abdominal pain, abdominal bloating, arm numbness, pruritus, feeling unwell, sursumvergence, akathisia, and dystonia, 1 each) and others (change of hospital, 5; failure to visit to the clinic and unknown, 3 each; and self-discontinuation and wish to withdraw from the medication, 2 each).

Kaplan-Meier curves were created to display the percentages of patients who continued. At week 52, 43.6\% of the patients $(n=41)$ remained on brexpiprazole with the maintenance dose being $2 \mathrm{mg} /$ day in $58.9 \%$ and $<2 \mathrm{mg} /$ day in $30.9 \%(P<0.01)$ (Figure 1), suggesting that those receiving brexpiprazole $2 \mathrm{mg} /$ day as a maintenance dose are more likely to remain on therapy than those receiving brexpiprazole $<2 \mathrm{mg} /$ day.

Of all patients treated with brexpiprazole in this study, the profiles of those who showed "marked improvements" (defined as scores of 1 on the CGI-I) from early after its

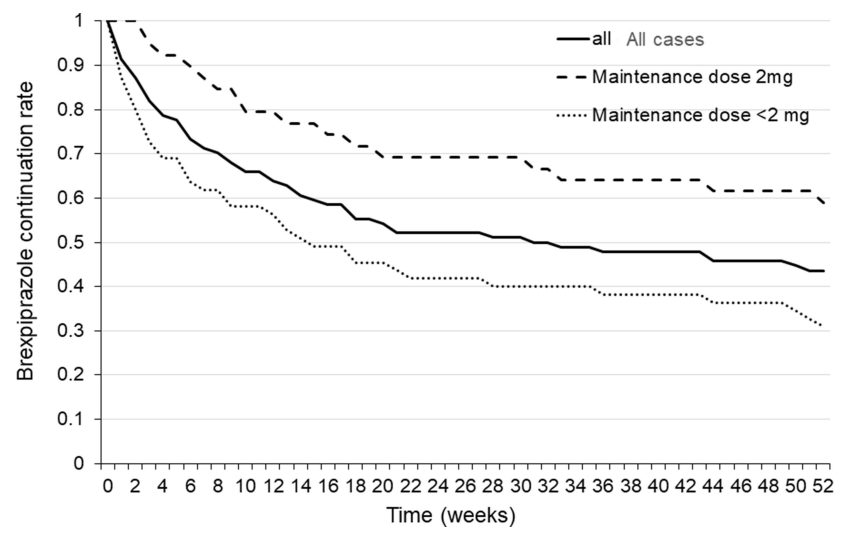

Figure I Brexpiprazole continuation rates over time (52 weeks).

initiation and remained on therapy for $\geq 1.5$ years are presented in Table 5. Of these, 7 and 3 patients had received brexpiprazole in hopes of achieving improvements in their positive symptoms and negative symptoms of schizophrenia, respectively. Given that those with first-episode/recurrent schizophrenia who had no prior history of antipsychotic use and who had switched to brexpiprazole from a prior antipsychotic participated in this study in equal numbers, the study suggested that brexpiprazole was effective even in those switching from another antipsychotic. Thus, overall, the present single-center experience appears to demonstrate, in agreement with the short- and long-term study results summarized above, that brexpiprazole represents an effective and viable option in the clinical setting as well.

\section{Proposed Treatment Algorithm Incorporating Brexpiprazole: A Psychiatrist's Perspective}

Schizophrenia is currently deemed a highly heterogeneous disease, ${ }^{36}$ and the current notion of disease heterogeneity refers to a composite of symptomatic phenotypes, risk factors, structural/functional psychopathology, and therapeutic response in first-episode and recurrent patients alike.

With all this in mind, we examined a total of 199 patients with schizophrenia for their frontal lobe function relative to their social adjustment ${ }^{37}$ and found that these patients could be broadly classified by their therapeutic response and social adjustment into 3 groups, ie, socially well adjusted, poorly adjusted, and highly treatmentresistant individuals (Figure 2A).

We examined a total of 1327 outpatients being treated at 3 psychiatric clinics including Himorogi Clinic for their antipsychotic drug load and social functioning ${ }^{38}$ and found 
Table 5 Profile of Patients with Marked Improvements* from Early After Initiation of Brexpiprazole and Remaining on the Drug for $\geq 1.5$ Years

\begin{tabular}{|l|l|l|l|l|l|}
\hline $\begin{array}{l}\text { Case } \\
\text { Number }\end{array}$ & Sex & $\begin{array}{l}\text { Age } \\
\text { (Years) }\end{array}$ & $\begin{array}{l}\text { Type of } \\
\text { Schizophrenia }\end{array}$ & Reason for Treatment & Type of Treatment \\
\hline 1 & Male & 29 & Undifferentiated type & Negative symptoms Blunted affect & Conversion \\
\hline 2 & Male & 55 & Residual type & Negative symptoms Blunted affect & Conversion \\
\hline 3 & Female & 54 & Residual type & Negative symptoms Blunted affect & Conversion \\
\hline 4 & Male & 52 & Schizoaffective disorder & Positive symptoms Hallucinations & Initial treatment for recurrence \\
\hline 5 & Female & 31 & Paranoid type & $\begin{array}{l}\text { Positive symptoms Delusion/ } \\
\text { Impulsivity }\end{array}$ & Initial treatment for recurrence \\
\hline 6 & Female & 34 & Paranoid type & Positive symptoms Hallucinations & Conversion \\
\hline 7 & Male & 48 & Paranoid type & $\begin{array}{l}\text { Positive symptoms Delusion/ } \\
\text { impulsivity }\end{array}$ & Conversion \\
\hline 8 & Female & 48 & Paranoid type & $\begin{array}{l}\text { Positive symptoms Delusions/ } \\
\text { impulsivity }\end{array}$ & $\begin{array}{l}\text { Initial treatment for first } \\
\text { episode }\end{array}$ \\
\hline 10 & Female & 29 & Paranoid type & Hallucinations and delusions & $\begin{array}{l}\text { Initial treatment for first } \\
\text { episode }\end{array}$ \\
\hline
\end{tabular}

Note: *Marked improvement was defined as scores of I on the CGI-I.

that the greater the number of antipsychotics and their mean total CP-equivalent dose, the lower their Global Assessment of Functioning (GAF) scores, thus showing a tendency toward decreased social functioning (Figure 3). The study also found that while $22 \%$ of the patients were fully employed and socially well adjusted, those who had been prescribed 3 or more antipsychotics with a mean total CP-equivalent dose of $\geq 1000 \mathrm{mg}$ (ie, those thought likely to be treatment-resistant) accounted for $13.6 \%$ of all patients evaluated.
A

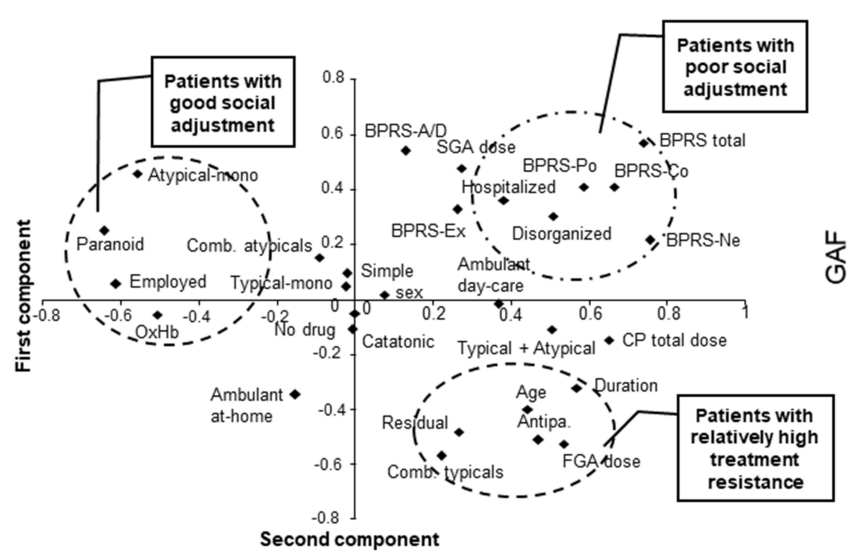

B 1. Type of schizophrenia (genetic factor)

2. Type and chlorpromazine-equivalent dose of antipsychotics used

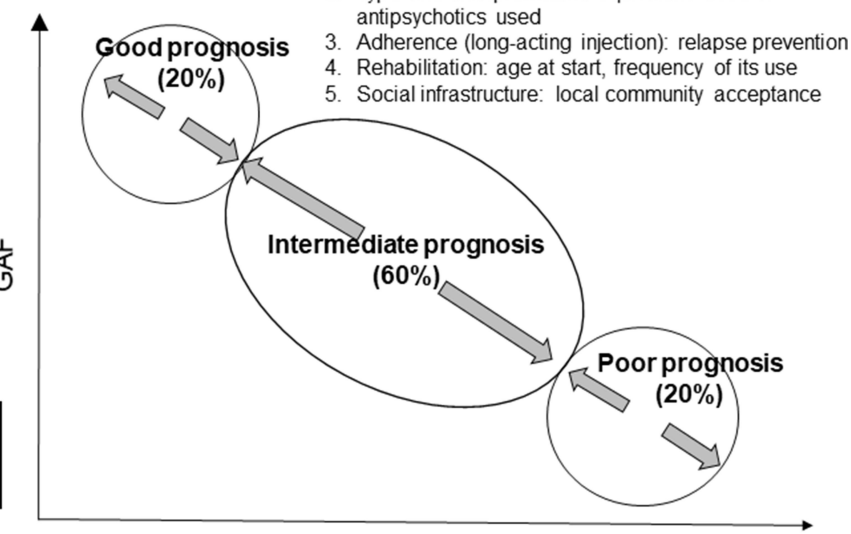

Genetic severity

Figure 2 (A) Scatter diagram of the first and second components in the principal component analysis. Reproduced with permission from Watanabe Y, Urakami T, Hongo S, Ohtsubo T. Frontal lobe function and social adjustment in patients with schizophrenia: near-infrared spectroscopy. Hum Psychopharmacol. 2015;30(I):28-4I. (C) 2014 The Authors. Human Psychopharmacology: Clinical and Experimental published by John Wiley \& Sons, Ltd. ${ }^{37}$ (B) Conceptual diagram for prognosis of schizophrenia.

Abbreviations: Antipa., antiparkinsonian drug; BPRS, Brief Psychiatric Rating Scale; A/D, anxiety-depression category; Co, cognitive symptom category; Ex, excitement category; $\mathrm{Ne}$, negative symptom category; Po, positive symptom category; Comb., combination; FGA, first-generation CP-equivalent; SGA, second-generation CPequivalent; $\mathrm{OxHb}$, oxyhemoglobin concentration. 


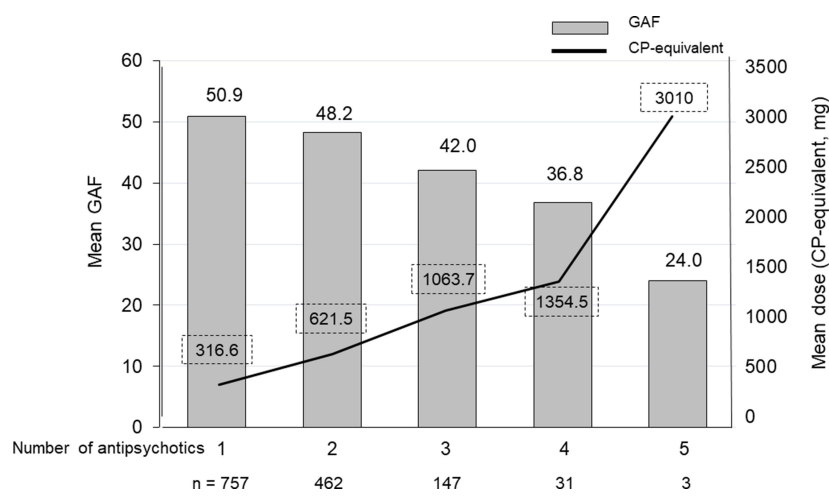

Figure 3 Relationship between the number and dose of antipsychotics prescribed and functioning in patients with schizophrenia. Reproduced from Watanabe Y, Azekawa T, Hongo S, Doi N, ljiri S, Hida H. Multicenter study on reintegration of ambulatory schizophrenia patients: preliminary investigation and data analysis for a cohort study (report I). J New Rem Clin. 2015;64(II):I389-I40I. ${ }^{38}$

Abbreviations: GAF, Global Assessment of Functioning; CP, chlorpromazine.

Based on these observations, a diagram has been created to conceptualize the prognosis of schizophrenia with the $\mathrm{X}$ and $\mathrm{Y}$ axes denoting genetic severity and GAF scores, respectively (Figure 2B), where 20\%,60\% and 20\% of patients are assumed to represent good-, intermediate-, and poor-prognosis populations, respectively, depending on the conditions under which they live with their disease, such as type of schizophrenia, type and CP-equivalent dose of antipsychotics used, adherence (relapse prevention), rehabilitation (age at start, frequency) and social infrastructure (local community acceptance). While, of these conditions, proper choice of antipsychotics and adjustment of their doses alone are amenable to control by psychiatrists, even good- prognosis individuals may end up in the intermediateprognosis category or the poor-prognosis category at worst.

Thus, given the importance of proper choice of antipsychotics for prognosis of schizophrenia, we have developed for clinic use and implemented a treatment algorithm incorporating brexpiprazole, based on the clinical trial results, as well as on our clinical experience in Japan (Figure 4), which shows how brexpiprazole may be best employed as a drug of first choice for the treatment of schizophrenia, given its favorable efficacy and safety profile.

Of note, a meta-analysis of second-generation versus firstgeneration antipsychotics by Leucht et al suggests that while antipsychotic therapy is beneficial for patients with schizophrenia, the choice of antipsychotic drugs should be made with their side effects in mind, given that the efficacy of a medication can only be weighed against its adverse effect profile. $^{39}$ In addition, in an investigation of death rates in schizophrenia and related psychoses, Healy et $\mathrm{al}^{40}$ found a 10year survival probability of $75 \%$ in the historical cohort (1875-1924) and a 90\% probability of survival in the contemporary cohort (1994-2010), while noting that the standardized mortality rates (SMR) quadrupled in both the historical and contemporary cohorts, with suicide and tuberculosis being the most common causes of death in the contemporary and historical cohorts with an SMR of 35 and an SMR of 9, respectively. In the contemporary cohort, deaths are reported to occur from cardiovascular causes in the elderly and from suicide in the young, suggesting that interventions may be warranted early in the course of disease as a point of high risk for suicide and

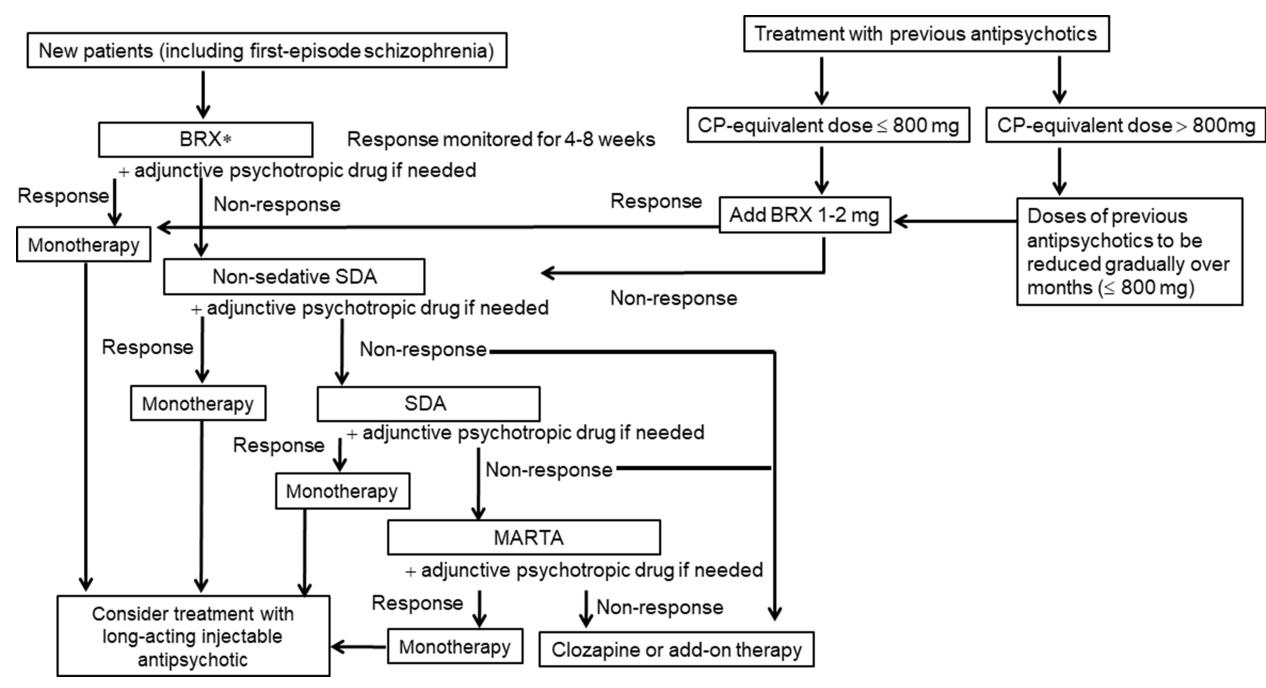

Figure $4 \mathrm{~A}$ proposed algorithm for antipsychotic treatment of schizophrenia in the clinic. *Brexpiprazole is used here as a first choice option; however, any other nonsedative SDA with low safety risk could also be an option. Adjunctive drug.

Abbreviations: BRX, brexpiprazole; CP, chlorpromazine; MARTA, multi-acting receptor-targeted antipsychotics; SDA, serotonin-dopamine antagonist. 
cardiovascular disease to give patients with schizophrenia a normal expectancy.

Thus, these considerations appear to support the use of the proposed algorithm using brexpiprazole as one of first-choice drugs in patients with schizophrenia differently depending on their history of prior antipsychotic use. In first-episode patients with schizophrenia, brexpiprazole monotherapy is started. On the other hand, in patient who are receiving the treatment with previous antipsychotic, brexpiprazole is switched from previous antipsychotic using overlapping or "plateau" crosstitration method, ie, starting brexpiprazole as add-on to previous antipsychotics in patients with a $\mathrm{CP}$-equivalent dose of $<800 \mathrm{mg}$. In patients with inadequate symptomatic improvements despite brexpiprazole monotherapy, however, adjunctive psychotropic drugs, such as benzodiazepine and valproate, may be added. In patients who have been successfully stepped down to brexpiprazole monotherapy, the use of a long-acting injectable antipsychotic may also be an option. Again, in patients shown to be refractory to any antipsychotic regimen thus formulated, the use of clozapine may be considered.

\section{Summary}

In summary, brexpiprazole has been shown in randomized, double-blind, placebo-controlled trials to have proven efficacy not only in improving the psychotic symptoms of schizophrenia but in preventing relapses. It is also suggested in both short- and long-term studies that brexpiprazole offers a favorable safety and tolerability profile. Given that schizophrenia remains a disease presumably requiring lifelong pharmacotherapy, brexpiprazole appears to play a more significant role to in the treatment of schizophrenia than other antipsychotics. Last but not least, given that the choice of an antipsychotic, as well as the adjustment of its dose, may lead to different responses and side effects in different patients, it remains vitally important for psychiatrists to treat each patient carefully while closely monitoring for drug response and adverse effects. Further research is eagerly awaited to provide more in-depth insight into the evolving role of brexpiprazole in schizophrenia. In addition, while several other dopamine $\mathrm{D}_{2}$ partial agonists, including cariprazine and lumateperone, have recently become available, unfortunately, these drugs are not available in Japan, and therefore have received only a passing mention in this article. We therefore hope to be able to provide a deeper insight into the dopamine partial agonists in schizophrenia based on our future experience with any of these newer antipsychotics in Japan.

\section{Acknowledgments}

The authors thank Mr. H. Itoh, Interface, for his writing and editorial assistance with the manuscript.

\section{Disclosure}

YW has received speaker's honoraria from Pfizer Japan Inc., Otsuka Pharmaceutical Co., Ltd., Janssen Pharmaceutical K. K., Meiji Seika Pharma Co., Ltd, Eli Lilly Japan K.K., MSD K.K. a subsidiary of Merck \& Co., Inc., Takeda Pharmaceutical Co., Ltd., Mochida Pharmaceutical Co., Ltd., Mitsubishi Tanabe Pharma Corp., and Sumitomo Dainippon Pharma Co., Ltd. SY is an employee of Otsuka Pharmaceutical Co., Ltd. TO has received lecture fees from Eli Lily, Pfizer, Takeda Pharmaceutical, Otsuka Pharmaceutical, and Sumitomo Dainippon Pharma, Yoshitomi Yakuhin, Mochida, Meiji Seika Pharma, and Kyowa Pharmaceutical, and research/grant support from Eisai, and Otsuka Pharmaceutical. TK has received speaker's honoraria from Astellas, Dainippon Sumitomo, Eli Lilly, Janssen, Otsuka, Takeda, Yoshitomi Yakuhin, and Pfizer. The authors report no other conflicts of interest in this work.

\section{References}

1. Saha S, Chant D, Welham J, McGrath JW. A systematic review of the prevalence of schizophrenia. PLoS Med. 2005;2(5):e141. doi:10.1371/journal.pmed.0020141

2. Simeone JC, Ward AJ, Rotella P, Collins J, Windisch R. An evaluation of variation in published estimates of schizophrenia prevalence from 1990-2013: a systematic literature review. BMC Psychiatry. 2015;15:193. doi:10.1186/s12888-015-0578-7

3. Sado M, Inagaki A, Koreki A, et al. The cost of schizophrenia in Japan. Neuropsychiatr Dis Treat. 2013;9:787-798. doi:10.2147/NDT.S41632

4. Ciompi L. Is there really a schizophrenia? The long-term course of psychotic phenomena. $\mathrm{Br} J$ Psychiatry. 1984;145(6):636-640. doi:10.1192/bjp.145.6.636

5. Harding CM, Zubin J, Strauss JS. Chronicity in schizophrenia: fact, partial fact, or artifact? Hosp Community Psychiatry. 1987;38 (5):477-486.

6. Huhn M, Nikolakopoulou A, Schneider-Thoma J, et al. Comparative efficacy and tolerability of 32 oral antipsychotics for the acute treatment of adults with multi-episode schizophrenia: a systematic review and network meta-analysis. Lancet. 2019;394(10202):939-951. doi:10.1016/S0140-6736(19)31135-3

7. Diefenderfer LA, Iuppa C. Brexpiprazole: a review of a new treatment option for schizophrenia and major depressive disorder. Ment Health Clin. 2017;7(5):207-212. doi:10.9740/mhc.2017.09.207

8. Kane JM. Treatment strategies to prevent relapse and encourage remission. J Clin Psychiatry. 2007;68(Suppl 14):27-30.

9. Ivkovic J, Lindsten A, George V, Eriksson H, Hobart M. Effect of brexpiprazole on prolactin: an analysis of short- and long-term studies in schizophrenia. J Clin Psychopharmacol. 2019;39(1):13-19. doi:10.1097/JCP.0000000000000979

10. Amada N, Akazawa H, Ohgi Y, et al. Brexpiprazole has a low risk of dopamine $\mathrm{D} 2$ receptor sensitization and inhibits rebound phenome related to D2 and serotonin 5-HT2A receptors in rats. Neuropsychopharmacol Rep. 2019;39(4):279-288. doi:10.1002/npr2.12076 
11. Citrome L, Ota A, Nagamizu K, Perry P, Weiller E, Baker RA. The effect of brexpiprazole (OPC-34712) and aripiprazole in adult patients with acute schizophrenia: results form a randomized, exploratory study. Int Clin Psychomaracol. 2016;31(4):192-201. doi:10.1097/YIC.0000000000000123

12. Carlsson A, Kehr W, Lindqvist M, Magnusson T, Atack CV Regulation of monoamine metabolism in the central nervous system. Pharmacol Rev. 1972;24(2):371-384.

13. Kikuchi T, Tottori K, Uwahodo Y, et al. 7-(4-[4-(2,3-Dichlorophenyl)1-piperazinyl]butyloxy)-3,4-dihydro-2(1H)-quinolinone (OPC-14597), a new putative antipsychotic drug with both presynaptic dopamine autoreceptor agonistic activity and postsynaptic D2 receptor antagonistic activity. J Pharmacol Exp Ther. 1995;274(1):329-336.

14. Maeda K, Sugino H, Akazawa H, et al. Brexpiprazole I: in vitro and in vivo characterization of a novel serotonin-dopamine activity modulator. $J$ Pharmacol Exp Ther. 2014;350(3):589-604. doi:10.1124/jpet.114.213793

15. Maeda K, Lerdrup L, Sugino $\mathrm{H}$, et al. Brexpiprazole II: antipsychotic-like and pro-cognitive effects of a novel serotonin-dopamine activity modulator. $J$ Pharmacol Exp Ther. 2014;350(3):605-614. doi:10.1124/jpet.114.213819

16. Yoshimi N, Fujita Y, Ohgi Y, Futamura T, Kikuchi T, Hashimoto K. Effects of brexpiprazole, a novel serotonin-dopamine activity modulator, on phencyclidine-induced cognitive deficits in mice: a role for serotonin 5-HT1A receptors. Pharmacol Biochem Behav 2014;124:245-249. doi:10.1016/j.pbb.2014.06.008

17. Correll CU, Skuban A, Hobart M, et al. Efficacy of brexpiprazole in patients with acute schizophrenia: review of three randomized, double-blind, placebo-controlled studies. Schizophr Res. 2016;174(1-3):82-92. doi:10.1016/j.schres.2016.04.012

18. Marder SR, Hakala MJ, Josiassen MK, et al. Brexpiprazole in patients with schizophrenia: overview of short- and long-term Phase 3 controlled studies. Acta Neuropsychiatr. 2017;29(5):278-290. doi:10.1017/neu.2016.57

19. Ishigooka J, Iwashita S, Tadori Y. Efficacy and safety of brexpiprazole for the treatment of acute schizophrenia in Japan: a 6-week, randomized, double-blind, placebo-controlled study. Psychiatry Clin Neurosci. 2018;72(9):692-700. doi:10.1111/pcn.12682

20. Correll CU, Skuban A, Ouyang J, et al. Efficacy and safety of brexpiprazole for the treatment of acute schizophrenia: a 6-week randomized, double-blind, placebo-controlled trial. Am J Psychiatry. 2015;172(9):870-880. doi:10.1176/appi.ajp.2015.14101275

21. Kane JM, Skuban A, Ouyang J, et al. A multicenter, randomized, double-blind, controlled phase 3 trial of fixed-dose brexpiprazole for the treatment of adults with acute schizophrenia. Schizophr Res. 2015;164(1-3):127-135. doi:10.1016/j.schres.2015.01.038

22. ClinicalTrials.gov. NCT01810380. Available from: https://clinical trials.gov/ct2/show $/$ NCT01810380?term $=$ NCT01810380\&draw $=$ 1\&rank=1. Accessed October 18, 2020.

23. van Erp TG, Baker RA, Cox K, et al. Effect of brexpiprazole on control of impulsivity in schizophrenia: a randomized functional magnetic resonance imaging study. Psychiatry Res Neuroimaging. 2020;301:111085. doi:10.1016/j.pscychresns.2020.111085

24. Malla A, Ota A, Nagamizu K, Perry P, Weiller E, Baker RA. The effect of brexpiprazole in adult outpatients with early-episode schizophrenia: an exploratory study. Int Clin Psychopharmacol. 2016;31 (6):307-314. doi:10.1097/YIC.0000000000000140

25. Fleischhacker WW, Hobart M, Ouyang J, et al. Efficacy and safety of brexpiprazole (OPC-34712) as maintenance treatment in adults with schizophrenia: a randomized, double-blind, placebo-controlled study. Int J Neuropsychopharmacol. 2017;20(1):11-21.

26. Forbes A, Hobart M, Ouyang J, Shi L, Pfister S, Hakala M. A long-term, open-label study to evaluate the safety and tolerability of brexpiprazole as maintenance treatment in adults with schizophrenia. Int J Neuropsychopharmacol. 2018;21(5):433-441. doi:10.1093/ijnp/ pyy002
27. Ishigooka J, Iwashita S, Tadori Y. Long-term safety and effectiveness of brexpiprazole in Japanese patients with schizophrenia: A 52-week, open-label study. Psychiatry Clin Neurosci. 2018;72(6):445-453.

28. Yoshimura Y, Shimizu H, Yamashita R, Washida K, Takeda T, Aoki S. Association between previous high-dose antipsychotic therapy and brexpiprazole discontinuation after the initiation of brexpiprazole in patients with schizophrenia or schizoaffective disorder. Int Clin Psychopharmacol. 2020;35(2):98-104. doi:10.1097/YIC.0000000000000296

29. Yan T, Greene M, Chang E, et al. Health care cost in patients with schizophrenia treated with brexpiprazole versus other oral atypical antipsychotic therapy. Clin Ther. 2020;42(1):77-93. doi:10.1016/j. clinthera.2019.11.009

30. Yang S, Chen L, Najoan E, et al. Polypharmacy and psychotropic drug loading in patients with schizophrenia in Asian countries: fourth survey of Research on Asian Prescription Patterns on antipsychotics. Psychiatry Clin Neurosci. 2018;72(8):572-579. doi:10.1111/pcn.12676

31. Kane JM, Skuban A, Hobart M, et al. Overview of short- and long-term tolerability and safety of brexpiprazole in patients with schizophrenia. Schizophr Res. 2016;174(1-3):93-98. doi:10.1016/j. schres.2016.04.013

32. Weiss C, Weiller E, Baker RA, et al. The effects of brexpiprazole and aripiprazole on body weight as monotherapy in patients with schizophrenia and as adjunctive treatment in patients with major depressive disorder: an analysis of short-term and long-term studies. Int Clin Psychopharmacol. 2018;33(5):255-260. doi:10.1097/ YIC.0000000000000226

33. Newcomer JW, Eriksson H, Zhang P, Weiller E, Weiss C. Changes in metabolic parameters and body weight in brexpiprazole-treated patients with acute schizophrenia: pooled analyses of phase 3 clinical studies. Curr Med Res Opin. 2018;34(12):2197-2205. doi:10.1080/ 03007995.2018.1498779

34. Correll CU, Shi L, Weiss C, et al. Successful switching of patients with acute schizophrenia from another antipsychotic to brexpiprazole: comparison of clinicians' choice of cross-titration schedules in a post hoc analysis of a randomized, double-blind, maintenance treatment study. CNS Spectr. 2019;24(5):507-517. doi:10.1017/ S1092852918001086

35. Yan T, Greene M, Chang E, et al. Health care cost in patients with schizophrenia treated with brexpiprazole versus other oral atypical antipsychotic therapy. Clin Ther. 2020;42(1):77-93. doi:10.1016/j. clinthera.2019.11.009

36. Wolfers T, Doan NT, Kaufmann T, et al. Mapping the heterogeneous phenotype of schizophrenia and bipolar disorder using normative models. JAMA Psychiatry. 2018;75(11):1146-1155. doi:10.1001/ jamapsychiatry.2018.2467

37. Watanabe Y, Urakami T, Hongo S, Ohtsubo T. Frontal lobe function and social adjustment in patients with schizophrenia: near-infrared spectroscopy. Hum Psychopharmacol. 2015;30(1):28-41. doi:10.1002/hup.2448

38. Watanabe $\mathrm{Y}$, Azekawa $\mathrm{T}$, Hongo $\mathrm{S}$, Doi $\mathrm{N}$, Ijiri $\mathrm{S}$, Hida $\mathrm{H}$. Multicenter study on reintegration of ambulatory schizophrenia patients: preliminary investigation and data analysis for a cohort study (report 1). J New Rem Clin. 2015;64(11):1389-1401.

39. Leucht $\mathrm{S}$, Komossa $\mathrm{K}$, Rummel-Kluge $\mathrm{C}$, et al. A meta-analysis of head-to-head comparisons of second-generation antipsychotics in the treatment of schizophrenia. Am J Psychiatry. 2009;166(2):152-163. doi:10.1176/appi.ajp.2008.08030368

40. Healy D, Le Noury J, Harris M, et al. Mortality in schizophrenia and related psychoses: data from two cohorts, 1875-1924 and 1994-2010. BMJ Open. 2012;2(5):e001810. doi:10.1136/bmjopen2012-001810 


\section{Publish your work in this journal}

Drug Design, Development and Therapy is an international, peerreviewed open-access journal that spans the spectrum of drug design and development through to clinical applications. Clinical outcomes, patient safety, and programs for the development and effective, safe, and sustained use of medicines are a feature of the journal, which has also been accepted for indexing on PubMed Central. The manuscript management system is completely online and includes a very quick and fair peer-review system, which is all easy to use. Visit http://www. dovepress.com/testimonials.php to read real quotes from published authors. 